Letter

\section{Pattern of cognitive deficits in severe COVID-19}

The severe form of COVID-19 tends to be associated with neurological deficits. ${ }^{12}$ Among patients with acute respiratory distress syndrome (ARDS), who benefited from mechanical ventilation and were examined after discontinuation of sedation and neuromuscular blockade, $69 \%$ presented agitation, $65 \%$ confusion, $67 \%$ corticospinal tract signs and 33\% dysexecutive syndrome. ${ }^{2}$

We describe here the pattern of cognitive deficits in a series of 13 consecutive inpatients hospitalised in the Lausanne University Hospital, whom we examined during the post-critical acute stage of severe COVID-19 (table 1). Inclusion criteria were COVID-19 diagnosed by PCR and ARDS that required intubation and mechanical ventilation in intensive care unit (ICU). Exclusion criteria were prior psychiatric or neurological diseases, including neurocognitive impairment or dementia. At the time of testing, patients were no longer sedated and ICU delirium symptoms, which were present in seven patients, resolved in six of them (P5-P7, P10, P11, P13) or subsided to a great extent (P12).

The neuropsychological evaluation comprised two standardised test batteries.
The Montreal Cognitive Assessment (MoCA; https://www.mocatest.org), which covers main cognitive functions, revealed normal cognitive performances in four patients (table 1; P1-P4), mild deficits in four (P5-P8) and moderate to severe deficits in five (P9-P13). MoCA subtests revealed selective cognitive pattern with lower performances in executive functions for patients with normal MoCA scores and more extensive cognitive impairment in executive, memory, attentional and visuospatial functions, with relatively preserved orientation and language, for patients with mild to severe MoCA deficits.

The Frontal Assessment Battery (FAB; www.psychdb.com/cognitive-testing/fab) revealed executive dysfunction in eight patients (table 1; P6-P13). Among the FAB subtests, the most affected was lexical fluency, impaired in all patients except in one (with normal MoCA: P3).

Pearson (r) and Spearman (rho) correlation analyses were conducted. MoCA and FAB scores were correlated $(\mathrm{r}=0.88 ; \mathrm{p}<0.001)$. Mental fatigue and cognitive slowness, assessed with observational scales, correlated with MoCA (respectively: $\mathrm{rho}=-0.67 ; \mathrm{p}=0.012$; rho $=-0.74 ; p=0.004)$ and $F A B$ scores (respectively: $\mathrm{rho}=-0.85 ; \mathrm{p}<0.001$; rho $=-0.72 ; \mathrm{p}=0.006)$. Age correlated with FAB $(r=-0.591 ; p=0.033)$ but not with MoCA scores. There was no significant correlation between MoCA or
FAB scores and the following measures: gender, length of ICU stay, duration of mechanical ventilation, delay between ICU discharge and cognitive assessment, mood and anxiety disturbances. Mood disturbance, assessed in self-report, was considerable (table $1 ; \geq 5 / 10$ ) in $38 \%$ of patients and $23 \%$ reported anxiety about breathing difficulties, fear of dying or reminiscences of intensive care. Seven patients presented ICU delirium (table 1); its occurrence was correlated with MoCA score $(\mathrm{rho}=-0.619 ; \mathrm{p}=0.024)$ and cognitive slowness $(r h o=0.585 ; \mathrm{p}=0.036)$, but not with $\mathrm{FAB}$, length of ICU stay, duration of mechanical ventilation, delay between ICU discharge and cognitive assessment, age, gender, mental fatigue, mood and anxiety disturbances.

Eleven patients had brain imaging. None of them sustained acute stroke or ischaemic damage; among the eight patients who had MRI-based morphometry, focal brain atrophy was, however, present in patients with normal (table 1; P1) or deficient performance at MoCA (P10-P13) as it was absent in patients with normal (P3, P4) or deficient performance at MoCA (P7). Four patients had lumbar puncture, revealing enhanced proteinorachia (P3, $\mathrm{P} 11, \mathrm{P} 13)$ and barrier index (P11, P13) or normal values (P12).

Two cognitive profiles characterise the post-critical acute phase of severe COVID-19: (1) normal score at MoCA, but tendency for lower performances

Table 1 Patient (P1-P13) characteristics and performance in cognitive tests

\begin{tabular}{|c|c|c|c|c|c|c|c|c|c|c|c|c|c|c|}
\hline Patients & $\begin{array}{l}\text { Age } \\
\text { (years) }\end{array}$ & Sex & $\begin{array}{l}\text { ICU stay } \\
\text { (days) }\end{array}$ & $\begin{array}{l}\text { Mechanical } \\
\text { ventilation } \\
\text { (days) }\end{array}$ & $\begin{array}{l}\text { ICU discharge } \\
\text { to cognitive } \\
\text { assessment } \\
\text { (days) }\end{array}$ & Brain atrophy & $\begin{array}{l}\text { ICU } \\
\text { delirium }\end{array}$ & $\begin{array}{l}\text { MoCA } \\
\text { scores } \\
(0-30)\end{array}$ & $\begin{array}{l}\text { FAB scores } \\
(0-18)\end{array}$ & $\begin{array}{l}\text { MoCA mean } \\
\text { subtest scores } \\
(0-6)\end{array}$ & $\begin{array}{l}\text { FAB mean subtest } \\
\text { scores } \\
(0-3)\end{array}$ & $\begin{array}{l}\text { Cognitive } \\
\text { slowness } \\
(0-3)\end{array}$ & $\begin{array}{l}\text { Mental } \\
\text { fatigue } \\
(0-3)\end{array}$ & $\begin{array}{l}\text { Mood } \\
(0-10) \text { and } \\
\text { anxiety* } \\
\text { disturbances }\end{array}$ \\
\hline P1 & $60 \mathrm{~s}$ & $\mathrm{~m}$ & 46 & 38 & 4 & rFgm; fv & $\mathrm{N}$ & 29 & 16.8 & \multirow{4}{*}{$\begin{array}{l}\text { Ex: } 3.63 \\
\text { Me: } 5.10 \\
\text { VS: } 5.63 \\
\text { La: } 5.70 \\
\text { At: } 5.75 \\
\text { Or: } 6.00\end{array}$} & \multirow{4}{*}{$\begin{array}{l}\text { Fl: } 1.75 \\
\text { Co: } 2.50 \\
\text { Pr: } 2.75 \\
\text { Inh: } 3.00 \\
\text { Int: } 3.00\end{array}$} & 1 & 2 & $8^{*}$ \\
\hline P2 & $60 \mathrm{~s}$ & $f$ & 12 & 11 & 6 & - & $\mathrm{N}$ & 28 & 15.6 & & & 2 & 2 & 2 \\
\hline P3 & $70 \mathrm{~s}$ & $\mathrm{~m}$ & 31 & 21 & 6 & None & $\mathrm{N}$ & 26.9 & 15.6 & & & 0 & 2 & 3 \\
\hline P4 & $60 \mathrm{~s}$ & $\mathrm{~m}$ & 67 & 50 & 10 & None & $\mathrm{N}$ & 26 & 14.4 & & & 1 & 2 & 1 \\
\hline P5 & $60 \mathrm{~s}$ & $\mathrm{~m}$ & 16 & 10 & 9 & None & $Y$ & 23 & 16.8 & \multirow{4}{*}{$\begin{array}{l}\text { Ex: } 2.25 \\
\text { Me: } 3.00 \\
\text { At: } 3.75 \\
\text { VS: } 4.13 \\
\text { Or: } 5.25 \\
\text { La: } 5.40\end{array}$} & \multirow{4}{*}{$\begin{array}{l}\text { Fl: } 1.25 \\
\text { Pr: } 2.00 \\
\text { Co: } 2.50 \\
\text { Inh: } 2.75 \\
\text { Int: } 2.75\end{array}$} & 2 & 1 & 5 \\
\hline P6 & $50 \mathrm{~s}$ & $\mathrm{~m}$ & 21 & 16 & 7 & - & Y & 22 & 13.2 & & & 2 & 2 & 0 \\
\hline P7 & $50 \mathrm{~s}$ & $\mathrm{~m}$ & 21 & 17 & 5 & None & $Y$ & 21 & 14.4 & & & 2 & 2 & 3 \\
\hline P8 & $70 \mathrm{~s}$ & $f$ & 14 & 13 & 4 & None & $\mathrm{N}$ & 19 & 9.6 & & & 1 & 2 & $2^{*}$ \\
\hline P9 & $60 \mathrm{~s}$ & $\mathrm{~m}$ & 21 & 17 & 4 & None & $\mathrm{N}$ & 17 & 7.2 & \multirow{7}{*}{$\begin{array}{l}\text { Me: } 0.48 \\
\text { VS: } 1.13 \\
\text { Ex: } 1.30 \\
\text { At: } 2.00 \\
\text { Or: } 3.40 \\
\text { La: } 4.08\end{array}$} & \multirow{5}{*}{$\begin{array}{l}\text { Fl: } 0.00 \\
\text { Inh: } 0.80 \\
\text { Pr: } 0.80 \\
\text { Int: } 1.00 \\
\text { Co: } 1.60\end{array}$} & 3 & 3 & $8^{*}$ \\
\hline P10 & $60 \mathrm{~s}$ & $\mathrm{~m}$ & 27 & 19 & 2 & $\begin{array}{l}\text { rlFgm; ITgm; } \\
\text { rlFwm; rlv; } \\
\text { tv; fv }\end{array}$ & $Y$ & 16.8 & 2.4 & & & 3 & 3 & 3 \\
\hline P11 & $50 \mathrm{~s}$ & $\mathrm{~m}$ & 40 & 23 & 2 & rlFgm; rlCgm & $Y$ & 13 & 9.6 & & & 2 & 2 & 2 \\
\hline $\mathrm{P} 12$ & $70 \mathrm{~s}$ & $\mathrm{~m}$ & 25 & 25 & 7 & $\begin{array}{l}\text { rFgm; rlFwm; } \\
\text { IPwm; rlOwm }\end{array}$ & $Y$ & 10 & 4.8 & & & 3 & 3 & 8 \\
\hline $\mathrm{P} 13$ & $70 \mathrm{~s}$ & $f$ & 24 & 19 & 6 & $\begin{array}{l}\text { rlFgm; rPgm; } \\
\text { rlTgm; rlv; tv }\end{array}$ & $Y$ & 4 & 1.2 & & & 3 & 3 & 6 \\
\hline MEAN: & 64.8 & & 28.1 & 21.5 & 5.5 & & & 19.7 & 10.9 & & & 1.9 & 2.2 & 3.9 \\
\hline SD: & 7.6 & & 15.2 & 11.2 & 2.4 & & & 7.5 & 5.5 & & & 1.0 & 0.6 & 2.8 \\
\hline
\end{tabular}


in executive than in other cognitive functions; (2) mild to severe deficits at MoCA with extensive cognitive impairment in executive, memory, attentional and visuospatial functions, but relatively preserved orientation and language, executive dysfunction being confirmed by the FAB score. These cognitive profiles together with mood and anxiety disturbances, which we observed in the acute stage, in the absence of stroke, are reminiscent of those reported in the aftermath of ARDS of other aetiologies, where up to $70 \%$ of ARDS survivors had presented at hospital discharge cognitive deficits, affecting predominantly attention, mental processing speed, memory and executive functions, ${ }^{3-5}$ with a high prevalence of depression and anxiety. ${ }^{5}$

Furthermore, cognitive impairment in severe COVID-19, as in ARDS of other aetiologies, ${ }^{5}$ does not correlate with length of mechanical ventilation or length of ICU stay and thus severity of the acute illness. However, the occurrence of ICU delirium tends to be associated with poorer cognitive performance. ${ }^{1}$

Structural damage, such as ischaemic or hypoxemic lesions of the hippocampus, basal ganglia or cerebellum lesions as well as brain atrophy (in particular hippocampal) or disruption of functional connectivity, which occur frequently in ARDS survivors, ${ }^{3} 4$ may contribute to cognitive dysfunction. In the context of COVID-19, stroke and perfusion abnormalities have been reported, ${ }^{1}{ }^{2}$ but were excluded here in all 11 patients, who had brain imaging during the acute stage.

Prior brain atrophy may confer worse outcome as shown for the risk to develop delirium and cognitive disorders in ARDS of other aetiologies. ${ }^{34}$ Patchy grey and/or white matter atrophy was present in five patients (of the eight who had MRI), most likely reflecting a prior condition; it was associated with cognitive impairment in four patients. However, brain atrophy did not always induce cognitive impairment and conversely, cognitive impairment was also present without imaging abnormalities, as in previous non-COVID-19 studies. $^{4}$
Our sparse data on cerebrospinal fluid suggest that increased blood-brain barrier permeability may contribute to neurological symptoms, as previously described for mild central nervous system inflammation in ICU patients. ${ }^{1}$

In conclusion, pattern of cognitive deficits, present during the acute stage in our 13 patients without history of cognitive, psychiatric or neurological disorders, is probably linked to critical illness as part of ARDS due to COVID-19, since it is very similar to those reported in ARDS of other aetiologies. Further investigations are needed to determine predictive factors and underlying neural mechanisms, and clarify with a long-term follow-up whether patients will completely recover.

\section{Valérie Beaud ๑ , ${ }^{1}$ Sonia Crottaz-Herbette $\odot,{ }^{1}$ Vincent Dunet $\odot$,' Julien Vaucher $\odot,^{3}$ Raphaël Bernard-Valnet $\oplus^{4}, 4$ \\ Renaud Du Pasquier $\odot, 4$ \\ Pierre-Alexandre Bart ${ }^{1},{ }^{3}$ Stephanie Clarke ()$^{1}$ \\ ${ }^{1}$ Service of Neuropsychology and Neurorehabilitation, \\ CHUV, Lausanne, Switzerland \\ ${ }^{2}$ Service of Diagnostic and Interventional Radiology, \\ CHUV, Lausanne, Switzerland \\ ${ }^{3}$ Service of Internal Medicine, CHUV, Lausanne, Switzerland \\ ${ }^{4}$ Service of Neurology, CHUV, Lausanne, Switzerland}

Correspondence to Valérie Beaud, Service of Neuropsychology and Neurorehabilitation, CHUV, Lausanne 1011,VD, Switzerland; valerie.beaud@chuv. ch

Contributors SC participated in study conception and design, interpretation and draft of the manuscript. VB participated in study conception and design, performed neuropsychological data acquisition and interpretation, and draft of the manuscript. SC-H performed

statistical analysis, interpretation and draft of the manuscript. VD performed radiological data acquisition and interpretation, and draft of the manuscript, RB-V performed neurological data acquisition and interpretation, and draft of the manuscript, JV, RDP and $P-A B$ participated in elaborating the large scale of this study and performed critical revision of the manuscript.

Funding This work was supported by the Biaggi de Blasys Foundation for SC-H.

Competing interests None declared.

Patient consent for publication Not required.

Ethics approval The procedure was approved by the Cantonal Ethics Committee of Vaud and informed consent was obtained in agreement with the requirements of the Ethics Committee.

Provenance and peer review Not commissioned; externally peer reviewed.

\section{(2) OPEN ACCESS}

Open access This is an open access article distributed in accordance with the Creative Commons Attribution Non Commercial (CC BY-NC 4.0) license, which permits others to distribute, remix, adapt, build upon this work non-commercially, and license their derivative works on different terms, provided the original work is properly cited, appropriate credit is given, any changes made indicated, and the use is non-commercial. See: http:// creativecommons.org/licenses/by-nc/4.0/.

(C) Author(s) (or their employer(s)) 2021. Re-use permitted under CC BY-NC. No commercial re-use. See rights and permissions. Published by BMJ.

Check for updates

To cite Beaud V, Crottaz-Herbette S, Dunet V, et al. J Neurol Neurosurg Psychiatry 2021;92:567-568.

Received 24 September 2020

Revised 3 November 2020

Accepted 4 November 2020

Published Online First 20 November 2020

J Neurol Neurosurg Psychiatry 2021;92:567-568. doi:10.1136/jnnp-2020-325173

\section{ORCID iDs}

Valérie Beaud http://orcid.org/0000-0001-5808-2166

Sonia Crottaz-Herbette http://orcid.org/0000-0003-

3944-3952

Vincent Dunet http://orcid.org/0000-0002-9897-4561 Julien Vaucher http://orcid.org/0000-0002-9462-8282

Raphaël Bernard-Valnet http://orcid.org/0000-00017447-344X

Renaud Du Pasquier http://orcid.org/0000-0002-27863434

Pierre-Alexandre Bart http://orcid.org/0000-00017685-8968

Stephanie Clarke http://orcid.org/0000-0001-93935718

\section{REFERENCES}

1 Helms J, Kremer S, Merdji H, et al. Delirium and encephalopathy in severe COVID-19: a cohort analysis of ICU patients. Crit Care 2020;24:491.

2 Helms J, Kremer S, Merdji H, et al. Neurologic features in severe SARS-CoV-2 infection. N Engl J Med 2020;382:2268-70.

3 Wilcox ME, Brummel NE, Archer K, et al. Cognitive dysfunction in ICU patients: risk factors, predictors, and rehabilitation interventions. Crit Care Med 2013:41:S81-98.

4 Hopkins RO, Gale SD, Weaver LK. Brain atrophy and cognitive impairment in survivors of acute respiratory distress syndrome. Brain Inj 2006;20:263-71.

5 Hopkins RO, Weaver LK, Collingridge D, et al. Two-Year cognitive, emotional, and quality-of-life outcomes in acute respiratory distress syndrome. Am J Respir Crit Care Med 2005;171:340-7. 